\title{
MULTIPROXY ANALYSIS (PHYTOLITHS, STABLE ISOTOPES, AND C/N) AS INDICATORS OF PALEOENVIRONMENTAL CHANGES IN A CERRADO SITE, SOUTHERN BRAZIL
}

\author{
LEANDRO DOMINGOS LUZ \\ Grupo de Estudos Multidisciplinares do Ambiente (GEMA), Universidade Estadual de Maringá, \\ Avenida Colombo, 5790, Jardim Universitário, 87020-900, Maringá, PR, Brazil. \\ luz.leandrod@gmail.com \\ MAURO PAROLIN \\ Laboratório de Estudos Paleoambientais, Universidade Estadual do Paraná - Campus Campo Mourão, \\ Avenida Comendador Norberto Marcondes, 733, 87303-100, Campo Mourão, PR, Brazil. \\ mauroparolin@gmail.com \\ LUIZ CARLOS RUIZ PESSENDA \\ Laboratório ${ }^{14} \mathrm{C}$, Centro de Energia Nuclear na Agricultura, Universidade de São Paulo, \\ Avenida Centenário, 303, Cp. 96, 13400-970, Piracicaba, SP, Brazil. \\ pessenda@cena.usp.br
}

GILIANE GESSICA RASBOLD

Programa de Pós-Graduação em Ecologia de Ambientes Aquáticos Continentais, Universidade Estadual de Maringá, Avenida Colombo, 5790, Jardim Universitário, 87020-900, Maringá, PR, Brazil.

grasbold@gmail.com

EDWARD LO

Department of Earth and Environmental Sciences, University of Kentucky, 101

Slone Building, 40506-0053, Lexington, KY, USA.

edward.lo@uky.edu

\begin{abstract}
Cerrado vegetation is associated with the semi-humid climate of the Central Brazil highlands. The presence of this vegetation in small and sparse areas in Paraná, Southern Brazil, can be associated with its past climate conditions. Paleoenvironmental changes of Cerrado vegetation in the Campo Mourão region $\left(24^{\circ} 06^{\prime} \mathrm{S}-52^{\circ} 23^{\prime} \mathrm{W}\right)$ are discussed in this study. The environmental changes were characterized using proxy data that includes stable isotopes and phytolith analyses in peaty sediments. Two drill cores obtained in alluvial plains were analyzed. Results were compared with the isotopic record $\left(\delta^{13} \mathrm{C}\right)$ from a trench in the Cerrado Ecological Station. Based on the results, we can infer that in $\sim 48,800 \pm 270 \mathrm{yrs}$ BP, the vegetation was mainly composed of grasses and at $\sim 42,280$ cal yrs BP a wetter climate allowed the expansion of arboreal vegetation. During the Middle Holocene ( $7280 \mathrm{cal}$ yrs BP), a drier period is also reported. Current climatic conditions (wet) were established since $\sim 3280 \mathrm{cal}$ yrs BP, after which the data suggests the expansion of subtropical forests over the Cerrado.
\end{abstract}

Keywords: Holocene, phytoliths, Pleistocene, stable isotopes.

RESUMO - A ocorrência de vegetação de cerrado está associada ao clima semiúmido e ao Planalto Central do Brasil. A presença dessa vegetação em pequenas e esparsas áreas no Estado do Paraná, Sul do Brasil, está associada às condições climáticas pretéritas. Mudanças paleoambientais da vegetação do Cerrado na região do Campo Mourão ( $\left.24^{\circ} 06^{\prime} \mathrm{S}-52^{\circ} 23^{\prime} \mathrm{O}\right)$ são discutidas neste trabalho. As alterações ambientais foram caracterizadas utilizando dados proxy, que incluem isótopos estáveis e análise de fitólitos em sedimentos turfosos. Foram analisados dois testemunhos sedimentares obtidos em planícies aluviais. Os resultados foram comparados com o registro isotópico $\left(\delta^{13} \mathrm{C}\right)$ de uma trincheira na Estação Ecológica do Cerrado. Com base nos resultados, podemos inferir que em $\sim 48.800$ anos AP, a vegetação era composta principalmente por gramíneas seguidas por um período provavelmente mais úmido com expansão da vegetação arbórea $\sim 42.280$ anos cal. AP. Um período mais seco até o Holoceno Médio ( 7.280 anos cal. AP) também é relatado. As condições climáticas modernas (úmidas) foram estabelecidas desde $\sim 3.280$ anos cal. AP; desde então é observado o avanço da vegetação arbórea sobre o Cerrado.

Palavras-chave: Holoceno, fitólitos, Pleistoceno, isótopos estáveis. 


\section{INTRODUCTION}

The Cerrado is a xeromorphic vegetation characteristic of a semi-humid climate and is often classified as "Brazilian Savanna" (Eiten, 1972). This vegetation is easily found in the central Brazilian highlands, covering $\sim 2$ million $\mathrm{km}^{2},(23 \%$ of the Brazilian territory) and is only exceeded by the Amazon biome (Klink \& Machado, 2005). The Cerrado vegetation has more than 7,000 known species of vascular plants, and about $44 \%$ is endemic flora. For this reason, the Cerrado is considered the richest tropical savanna in the world, with considerable ecological importance (Eiten, 1972; Pinheiro \& Monteiro, 2010).

Nevertheless, the Cerrado vegetation in the southern part of Brazil is poorly known, and some hypotheses about its presence are linked with its past environment. Maack (1949) suggested that the Cerrado vegetation that expanded during a dry/less humid climate occurred almost entirely on the South American continent in the Late Pleistocene. Recently, the use of multiproxy data in sedimentary cores, such as phytolith analyses (e.g. Piperno \& Becker, 1996; Alexandre et al., 1999; Borba-Roschel et al., 2006; Coe et al., 2013; Calegari et al., 2013, 2015), palynology (e.g. Behling, 1998, 2002, 2006; Behling \& Negrelle, 2001; Behling \& Safford, 2010; Cohen et al., 2012), stable isotopes (e.g. Pessenda et al., 1996, 1998a, b; Freitas et al., 2001), and others, have provided significant information about the past environment changes in different biomes in Brazil.

Carbon isotope signatures $\left(\delta^{13} \mathrm{C}\right)$ from the soil organic matter (SOM) has been widely regarded as a useful marker of environmental change, providing relevant proxy information about the characteristics of past environments in the Cerrado (Ledru et al., 1996; Pessenda et al., 1998a, 2004; Cohen et al., 2012). Through stable carbon isotope analysis, it is possible to distinguish the $\mathrm{C}_{3}\left(\delta^{13} \mathrm{C}=-32\right.$ through $\left.-20 \%\right)$ and $\mathrm{C}_{4}\left(\delta^{13} \mathrm{C}=\right.$ -17 through $-9 \%$ o) photosynthetic pathway in plants. The composition of $\delta^{13} \mathrm{C}_{\text {in }} \mathrm{C}_{3}$ and $\mathrm{C}_{4}$ plants differ in approximately 14\%o (Boutton, 1991). Furthermore, the use of $\delta^{13} \mathrm{C}$ has been combined with $\mathrm{C} / \mathrm{N}$ in many studies to distinguish aquatic and terrestrial materials preserved in peat sediments (Meyers, 1994; Zani et al., 2012). On the other hand, the $\mathrm{C} / \mathrm{N}$ ratio is obtained from Total Organic Carbon (TOC) and the Total Nitrogen (TN), which helps to distinguish organic matter produced from freshwater phytoplankton $(\mathrm{C} / \mathrm{N}: 4.0-10.0)$ and terrestrial plants (C/N: $\geq 12$ ) (Meyers, 1994; Zani et al., 2012).

Recently, the phytolith analysis has played an important role in paleoenvironmental reconstruction (Piperno \& Becker, 1996; Alexandre et al., 1999; Borba-Roschel et al., 2006). Furthermore, the phytolith analysis can also be associated with stable carbon isotope analysis (Coe et al., 2013; Calegari et al., 2013). The formation of phytoliths $\left(\mathrm{SiO}_{2} \cdot \mathrm{nH}_{2} \mathrm{O}\right)$ starts when silica $(\mathrm{Si})$ is absorbed by plants in a soluble form $\left(\mathrm{H}_{4} \mathrm{SiO}_{4}\right)$ from groundwater by the roots system and is accumulated as opal in micrometer shapes especially in leaves (Twiss et al., 1969; Piperno, 1989; Kealhofer \& Piperno, 1998). As an inorganic material, phytoliths are relatively stable in soils and sediments for thousands of years and for this reason they are an important tool for paleoclimatic and paleoenvironmental reconstructions (Piperno \& Becker, 1996; Alexandre et al., 1999; Borba-Roschel et al., 2006; Coe et al., 2013; Calegari et al., 2013).

This paper aims to identify and track paleoenvironmental changes in the Cerrado vegetation from the Campo Mourão region, using a multi-proxy approach, including radiocarbon dating, phytolith analysis, stable isotopes $\left(\delta^{13} \mathrm{C}\right.$ and $\left.\delta^{15} \mathrm{~N}\right)$, and elementary data (TOC, TN, and $\mathrm{C} / \mathrm{N})$.

\section{MATERIAL AND METHODS}

\section{Study site}

The Campo Mourão plateau is composed by the basalts known as Serra Geral Formation. The formation of oxisols occurs mainly in areas of flattened relief and nitosols in areas with a steeper slope. Both types of soils have been widely used for intensive commercial agriculture since the decade of 1970. In the floodplains, where the terrains remain saturated in water practically all year, the formation of hydromorphic soils occurs, usually covered with peaty sediments (Luz \& Parolin, 2013). The regional climate is classified as $\mathrm{Cfb}$ type, humid subtropical, with hot summers and concentrated rains without a dry season, according to the Köppen-Geiger classification. The average temperature in summer is higher than $22^{\circ} \mathrm{C}$ and in winter below $18^{\circ} \mathrm{C}$, with an average precipitation of $\sim 1,750$ $\mathrm{mm} / \mathrm{yr}$ (Andrade \& Néry, 2003). Campo Mourão Municipality can be considered a transitional vegetation area, with the presence of the native Araucaria Forest, the Semi-deciduous Forest, and the Cerrado (Figure 1).

\section{Floristic composition and carbon isotope signature of modern plants}

Floristic identification of the dominant species in a radius of $\sim 200 \mathrm{~m}$ from the sampling sites was performed by the herbarium staff (HCF) of the Universidade Tecnológica Federal do Paraná (UTFPR). In the core site, the vegetation is composed mainly by the following families: Acanthaceae, Asteraceae, Blechnaceae, Convolvulaceae, Cyperaceae, Fabaceae, Melastomataceae, Piperaceae, Poaceae, Pontederiaceae, Pteridaceae, Rubiaceae, Sapindaceae, Selaginellaceae, Thelypteridaceae, Woodsiaceae, and Xyridacea. Samples of leaves and stems of the most representative species were sent to the Center for Nuclear Energy in Agriculture $\left({ }^{14} \mathrm{C}\right.$ Laboratory, CENA), University of São Paulo, for carbon isotope determination.

\section{Sampling and analytical procedures}

Three sampling points were analyzed, two peaty cores in a transitional area of Araucaria Forest and a trench at the Cerrado Ecological Station (CES). The peaty sediment cores were collected using a vibro-core system (Martin et al., 1995) with a $6 \mathrm{~m}$ long and $10 \mathrm{~cm}$ diameter aluminum tube, at the Ranchinho (RRC, 24 $06^{\prime} 43^{\prime \prime} \mathrm{S}-52^{\circ} 23^{\prime} 04^{\prime \prime} \mathrm{W}$ ) and the

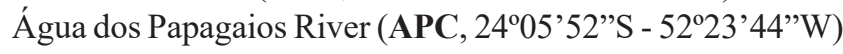
alluvial plain. Both cores were $110 \mathrm{~cm}$ long and were collected 


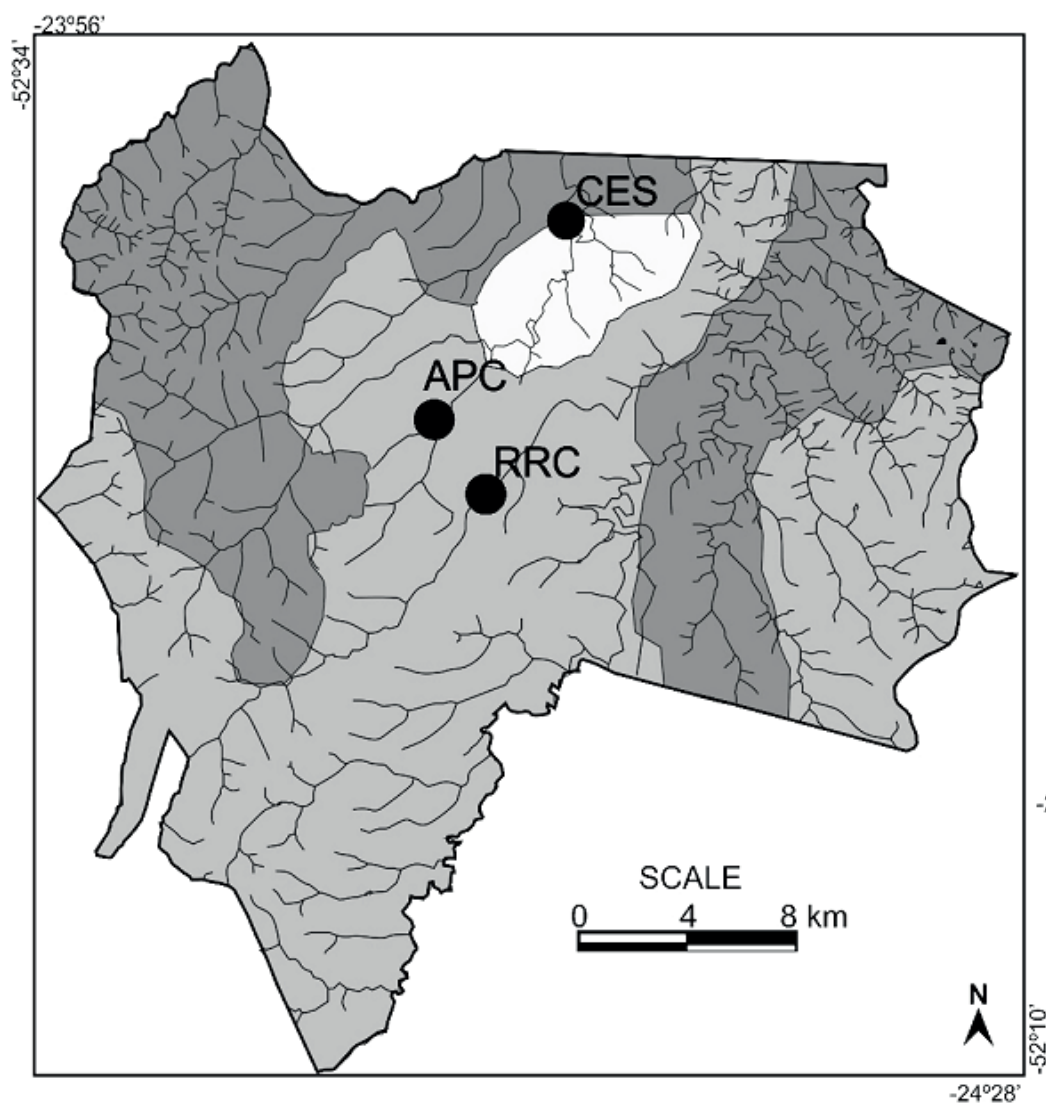

\section{SAMPLING LOCATION \\ Campo Mourão Municipality}

\section{CES - Cerrado Ecological Station \\ RRC - Rachinho core \\ APC - Água dos Papagaios core \\ Araucaria Forest \\ Semi-decidous Forest \\ Cerrado (wooded savanna)}

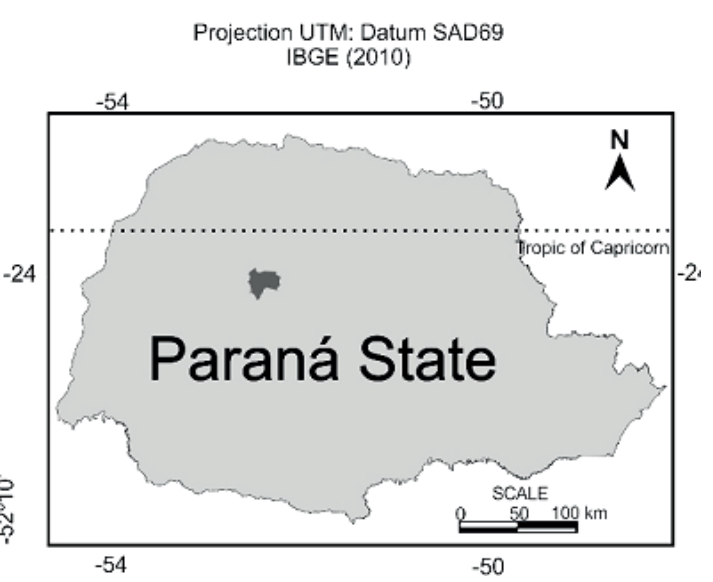

Figure 1. Sampling location in the Campo Mourão Municipality.

on the right margin in the middle of the alluvial plain. The cores were subsampled $\left(5 \mathrm{~cm}^{3}\right)$ in $3 \mathrm{~cm}$ intervals in the RRC and 4 $\mathrm{cm}$ intervals in the APC for phytolith analysis. Soil samples from the Cerrado Ecological Station (CES) were obtained at $10 \mathrm{~cm}$ intervals up to $370 \mathrm{~cm}$ depth for carbon isotope analysis $\left(\delta^{13} \mathrm{C}\right)$ and a charcoal sample for ${ }^{14} \mathrm{C}$ dating. Samples of CES trench were also sent to the ${ }^{14} \mathrm{C}$ Laboratory of CENA.

\section{Carbon and nitrogen elementary and isotope analysis}

Subsamples of the peaty cores $\left(10 \mathrm{~cm}^{3}\right)$ were dried at $60^{\circ} \mathrm{C}$ for 24 hours and sent for $\mathrm{C}$ and $\mathrm{N}$ elementary and isotope analysis. The $\delta^{13} \mathrm{C}, \delta^{15} \mathrm{~N}$, Total Organic Carbon TOC (\%), Total Nitrogen - TN (\%) analyses were carried out at the Center for Applied Isotopes Studies (CAIS) of the University of Georgia (USA) and at the ${ }^{14} \mathrm{C}$ Laboratory of CENA (Table 1). The isotope composition $\left(\delta^{13} \mathrm{C}\right.$ and $\left.\delta^{15} \mathrm{~N}\right)$, with analytical precision of $\pm 0.2 \%$, are obtained through the following equations:

$$
\begin{aligned}
& \text { (1) } \delta^{13} \mathrm{C}(\%)=\left[\mathrm{R}_{\text {sample }} / \mathrm{R}_{\text {standard }}-1\right] \times 1000 \\
& \text { (2) } \delta^{15} \mathrm{~N}_{\text {sample }}=\left[\mathrm{R}_{\text {sample2 }}-\mathrm{R}_{\text {air }} / \mathrm{R}_{\text {air }}\right] \times 1000
\end{aligned}
$$

where: $\mathrm{R}_{\text {sample } 1}$ and $\mathrm{R}_{\text {sample } 2}$ are, respectively, the ${ }^{13} \mathrm{C} /{ }^{12} \mathrm{C}$ and ratio ${ }^{15} \mathrm{~N} /{ }^{14} \mathrm{~N}$ of the sample, $\mathrm{R}_{\text {standard }}$ refers to the ${ }^{13} \mathrm{C} /{ }^{12} \mathrm{C}$ ratio of the standard and $\mathrm{R}_{\text {air }}$ refers to the ${ }^{15} \mathrm{~N} /{ }^{14} \mathrm{~N}$ ratio of the atmospheric air (Pessenda et al., 1996, 1998a,b).
The radiocarbon dating was carried out at the AMS Laboratory of the Center for Applied Isotope Studies - CAIS (Table 1). For dating calibration, we used the software Calib 7.1 (Stuiver, et al., 2017). The ages were calibrated using the Intcal13 calibration curve, with $2 \sigma$ error (Reimer et al., 2013). One of the five radiocarbon ages was not able to be calibrated because it was out of range.

\section{Phytolith extraction, counting, and classification}

Phytoliths were extracted at the Paleoenvironmental Studies Laboratory (LEPAFE), following a modified protocol of Faegri \& Iversen (1975): (i) Samples of $1 \mathrm{~cm}^{3}$ were collected in each $3 \mathrm{~cm}$ ( $\mathrm{RC}, \mathrm{n}=38$ samples) and $4 \mathrm{~cm}$ (APC, $\mathrm{n}=28$ samples). In a Becker, $20 \mathrm{ml}$ of hydrochloric acid ( $10 \%$ concentration) were added to the samples to remove carbonates; (ii) the sediment samples were heated up to boil in a hotplate $\left(2\right.$ hours to $\left.60^{\circ} \mathrm{C}\right)$ with $50 \mathrm{ml}$ of potassium hydroxide (10\%); (iii) the samples were centrifuged (500 RPM for 3 minutes) with distilled water for 3 times; (iv) afterwards, we added zinc chloride solution with $2.4 \mathrm{~g} / \mathrm{cm}^{3}$ density; (v) the samples were centrifuged (500 RPM for $3 \mathrm{~min}$ ); (vi) the supernatant containing the particles with density less than 2.4 $\mathrm{g} / \mathrm{cm}^{3}$ was removed to separate phytoliths from other minerals; (vii) later, the samples were centrifuged (500 RPM for 3 minutes) with distilled water until the total elimination of the chloride; (viii) For each sample, 5 slides were made with 50 $\mu 1$ of sample material and covered using Entellan ${ }^{\circledR}$. 
Table 1. Samples analyzed in each sediment core. Abbreviations: CAIS, Center for Applied Isotopes Studies, University of Georgia, USA; CENA, Stable Isotope Laboratory, Center for Nuclear Energy in Agriculture, University of São Paulo, Brazil; TN, Total Nitrogen; TOC, Total Organic Carbon.

\begin{tabular}{|c|c|c|c|c|c|c|c|}
\hline \multicolumn{8}{|c|}{ Ranchinho River Core (RRC) } \\
\hline Sample $(\mathrm{cm})$ & ${ }^{14} \mathrm{C}$ Dating & $\delta^{13} \mathrm{C}(\%)$ & $\delta^{15} \mathrm{~N}(\%)$ & TOC $(\%)$ & $\mathrm{TN}(\%)$ & CAIS & CENA \\
\hline 0 & & $\mathrm{x}$ & $\mathrm{x}$ & $\mathrm{x}$ & $\mathrm{x}$ & & $\mathrm{x}$ \\
\hline $10-07$ & & $\mathrm{x}$ & $\mathrm{x}$ & $\mathrm{x}$ & $\mathrm{x}$ & & $\mathrm{x}$ \\
\hline $19-16$ & & $\mathrm{x}$ & $\mathrm{x}$ & $\mathrm{x}$ & $\mathrm{x}$ & & $\mathrm{x}$ \\
\hline $28-25$ & & $\mathrm{x}$ & & $\mathrm{x}$ & $\mathrm{x}$ & $\mathrm{x}$ & \\
\hline $34-31$ & & $\mathrm{x}$ & $\mathrm{x}$ & $\mathrm{x}$ & $\mathrm{x}$ & & $\mathrm{x}$ \\
\hline 45 & $\mathrm{x}$ & $\mathrm{x}$ & & & & $\mathrm{x}$ & \\
\hline $58-55$ & & $\mathrm{x}$ & & $\mathrm{x}$ & $\mathrm{x}$ & $\mathrm{x}$ & \\
\hline $67-64$ & & $\mathrm{x}$ & $\mathrm{x}$ & $\mathrm{x}$ & $\mathrm{x}$ & & $\mathrm{x}$ \\
\hline $79-75$ & & $\mathrm{x}$ & & $\mathrm{x}$ & $\mathrm{x}$ & $\mathrm{x}$ & \\
\hline $88-85$ & & $\mathrm{x}$ & $\mathrm{x}$ & $\mathrm{x}$ & $\mathrm{x}$ & & $\mathrm{x}$ \\
\hline $97-94$ & $\mathrm{x}$ & $\mathrm{x}$ & & & & $\mathrm{x}$ & \\
\hline \multicolumn{8}{|c|}{ Água dos Papagaios Core (APC) } \\
\hline All samples & & $\mathrm{x}$ & $\mathrm{x}$ & $\mathrm{x}$ & $\mathrm{x}$ & & $\mathrm{x}$ \\
\hline 45 & $\mathrm{x}$ & & & & & $\mathrm{x}$ & \\
\hline 75 & $\mathrm{x}$ & & & & & $\mathrm{x}$ & \\
\hline \multicolumn{8}{|c|}{ Trench at Cerrado Ecological Station (CES) } \\
\hline All samples & & $\mathrm{x}$ & & & & & $\mathrm{x}$ \\
\hline $120-130$ & $\mathrm{x}$ & & & & & $\mathrm{x}$ & \\
\hline
\end{tabular}

Two hundred phytolith grains were counted in each sample and classified. We followed the International Code for Phytoliths Nomenclature 1.0 (ICPN) (Madella et al., 2005). The ICPN uses as morphotype descriptors: a) the shape; b) the texture and/or ornamentation and c) the anatomical origin. For phytolith morphology identification, we used other studies published in the scientific literature, e.g. Twiss et al. (1969), Rapp \& Mulholland (1992), Meunier \& Colin (2001), Piperno (2006) and Coe \& Osterrieth (2014). In addition, we used the reference collection of the Paleoenvironmental Studies Laboratory (LEPAFE).

Phytolith concentration for each sample was established by counting the absolute number of morphotypes viewed in three arbitrary transects. The microscopic slides were catalogued and stored in LEPAFE by the codes: Col. Agrícola (APC) (L163.C16; L164.C16 and L165.C16) and Rio Ranchinho (RRC) (L147.C14; L148.C14; L149.C14 e L150.C14). TiliaGraph ${ }^{\circledR}$ software was used for the graphical reproduction of the results and to load the cluster analysis used for establishing the phytolith zones.

\section{RESULTS}

\section{Floristic and isotope signature of modern plants}

Herbaceous species are predominant in the study area: Melica sarmentosa Nees., Pseudechinolaena polystachya (Kunth) Stapf with some arboreal species, Acisanthera variabilis (Mart. and Schrank) Triana, Tibouchina cerastifolia Cogn., Mimosa pilulifera Benth. Isotopic signals of the modern plants in the study area (Table 2) reflect the mixture of $\mathrm{C}_{3}$ and $\mathrm{C}_{4}$ plants. The isotopic signal of $-20.17 \%$ obtained from the litter sample located in the RRC support this value.

\section{${ }^{14} \mathrm{C}$ dating}

Four sedimentary units were dated in the sedimentary cores, and one age was obtained in the soil profile at the CES site (Table 3). RRC $(95 \mathrm{~cm}$ ) was dated $48,800 \pm 270 \mathrm{yrs}$ BP and $\sim 42,183 \mathrm{cal}$ yrs BP $(45 \mathrm{~cm})$. APC was dated $7280 \mathrm{cal} \mathrm{yrs}$ BP $(75 \mathrm{~cm})$ and $\sim 3282 \mathrm{cal}$ yrs BP $(45 \mathrm{~cm})$. CES soil profile was dated to $\sim 5820 \mathrm{cal}$ yrs BP $(120-130 \mathrm{~cm})$. 
Table 2. Floristic composition of the study area and their respective $\delta^{13} \mathrm{C}$ and photosynthetic pathway.

\begin{tabular}{|c|c|c|c|}
\hline Family & Specie & $\delta^{13} \mathrm{C}(\%)$ & Photosynthetic pathway \\
\hline Annonaceae & Anona coriacea Mart. & -29.91 & $\mathrm{C}_{3}$ \\
\hline Arecaceae & Butia paraguayensis (Barb. Rodr.) L. H. Bailey & -29.1 & $\mathrm{C}_{3}$ \\
\hline Cucurbitaceae & Cayaponia espelina (Silva Manso) Cogn. & -31.93 & $\mathrm{C}_{3}$ \\
\hline Cyperaceae & Rhynchospora corymbora (L.) Britton. & -28.77 & $\mathrm{C}_{3}$ \\
\hline Erythroxylaceae & Erythroxylum suberosum St. Hil. & -30.37 & $\mathrm{C}_{3}$ \\
\hline Fabaceae & Anadenanthera falcata (Benth.) Altschul & -30.07 & $\mathrm{C}_{3}$ \\
\hline Melastomataceae & Leandra lacunosa Cogn. & -29.83 & $\mathrm{C}_{3}$ \\
\hline Myrtaceae & Myrcia rastrata DC. & -31.48 & $\mathrm{C}_{3}$ \\
\hline Poaceae & Pennisetum purpureum Schumach & -12.3 & $\mathrm{C}_{4}$ \\
\hline Poaceae & Trichachne insularis (L.) Nees & -12.63 & $\mathrm{C}_{4}$ \\
\hline Poaceae & Bracharia decumbens Stapf & -12.3 & $\mathrm{C}_{4}$ \\
\hline Poaceae & Dactyloctenium aegyptium (L.) Willd. & -13.59 & $\mathrm{C}_{4}$ \\
\hline Polypodiaceae & Polypodium & -29.28 & $\mathrm{C}_{3}$ \\
\hline Smilacaceae & Smilax campestris Grisebach. & -28.64 & $\mathrm{C}_{3}$ \\
\hline Vochysiaceae & Vochysia tucanorum Mart. & -30.65 & $\mathrm{C}_{3}$ \\
\hline
\end{tabular}

Table 3. ${ }^{14} \mathrm{C}$ dating of selected samples. Abbreviations: APC, Água dos Papagaios core; CES, Cerrado Ecological Station; RRC, Ranchinho Core; UGAMS - AMS Laboratory, University of Georgia, USA.

\begin{tabular}{|c|c|c|c|c|c|c|c|}
\hline $\begin{array}{l}\text { Lab Code } \\
\text { (UGAMS) }\end{array}$ & Sample & $\begin{array}{c}\text { Depth } \\
(\mathrm{cm})\end{array}$ & Sample Material & $\begin{array}{c}\text { Age } \\
\text { (yrs BP) }\end{array}$ & Error & $\begin{array}{c}2-\sigma \text { range } \\
\text { (cal yr BP) }\end{array}$ & $\begin{array}{c}\text { Median } \\
\text { calibrated age } \\
\text { (cal yrs BP) }\end{array}$ \\
\hline 10581 & $\mathrm{APC}$ & 45 & Sediment & 3060 & 25 & $3208-3356$ & $\sim 3282$ \\
\hline 10580 & CES & 120 & Charcoal & 5060 & 30 & $5738-5902$ & $\sim 5820$ \\
\hline 10582 & APC & 75 & Sediment & 6340 & 25 & $7239-7322$ & $\sim 7280$ \\
\hline 11842 & RRC & 45 & Sediment & 37,920 & 160 & $41,895-42,477$ & $\sim 42,183$ \\
\hline 11843 & $\mathrm{RRC}$ & 95 & Sediment & 48,800 & 270 & * & $*$ \\
\hline
\end{tabular}

*Out of range (Reimer et al., 2013).

\section{Elementary and isotopic analysis of $\mathbf{C}$ and $\mathbf{N}$}

The concentrations of TOC ranged from $7.8 \%(87 \mathrm{~cm})$ to $26.98 \%(8 \mathrm{~cm})$ in the RRC, $0.48 \%(110 \mathrm{~cm})$ to $27.68 \%$ $(15 \mathrm{~cm})$ in the APC, and $0.28 \%(370 \mathrm{~cm})$ to $2.1 \%(1 \mathrm{~cm})$ in the CES. The TN ranged from $0.84 \%(77 \mathrm{~cm})$ to $15.15 \%(8$ $\mathrm{cm})$ in the RRC and $0.04 \%(110 \mathrm{~cm})$ to $1.86 \%(15 \mathrm{~cm})$ in the APC (Tables 4-6). In the RRC the relation between $\delta^{13} \mathrm{C}$ and $\mathrm{C} / \mathrm{N}$ suggest the presence of algae matter in the entire core. In contrast, APC presents more $\mathrm{C}_{4}$ terrestrial plants in sediments older than $\sim 7280$ cal yrs BP and a tendency to harbor algae in younger sediments (Figure 2 ). The $\mathrm{C} / \mathrm{N}$ values ranged between $1.42(0 \mathrm{~cm})$ to $15.61(27 \mathrm{~cm})$ in the $\mathrm{RRC}$ and $12.03(110 \mathrm{~cm})$ to $56.47(80 \mathrm{~cm})$ in the APC. The $\delta^{13} \mathrm{C}$ values ranged from $-20.17 \%$ (base layer) to $-14.09 \%$ ( $77 \mathrm{~cm})$ in the RRC, $-19.2 \% 0(10 \mathrm{~cm})$ to $-14.24 \% 0(110 \mathrm{~cm})$ in the APC, and $-18.94 \%$ (A horizon) to $-14 \%$ ( $320 \mathrm{~cm}$ ) in the CES. The $\delta^{15} \mathrm{~N}$ ranged from $2.49 \%$ to $18.9 \%$ at the APC site and from $2.78 \%$ to $11 \%$ at the RRC site.

\section{Phytolith zones}

The RRC phytolith assemblage is mainly composed by Elongate, Parallelepipedal bulliform and Cuneiform bulliform morphotypes (Figures 3-4). A greater diversity of morphotypes was reported from 25 -cm-depth toward the top, with the presence of short cell morphotypes, such as Bilobate, Saddle, Rondel, Cross, and Trapeziform. The phytolith assemblage of APC presents greater diversity of morphotypes in relation to the RRC, with a proper distribution of short cell forms in the sedimentary profile (Figures 3-4).

Ranchinho River Core - RRC. Four phytolith zones were defined in the RRC (Figure 4, Appendix 1):

- Zone I (110-50 cm) was dated $\sim 48,800 \pm 270 \mathrm{yrs}$ BP $(95 \mathrm{~cm})$. Parallelepipedal bulliform, Cuneiform bulliform and Elongate psilate were the most representative morphotypes of this zone. These morphotypes were also more weathered than the morphotypes found in the superficial layers. 
Água dos Papagaios Core (APC)

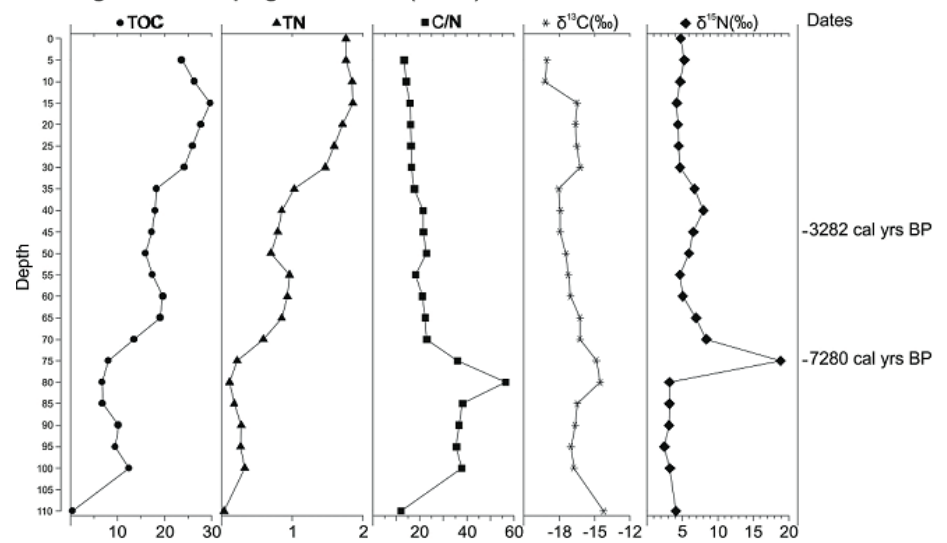

Ranchinho Core (RRC)

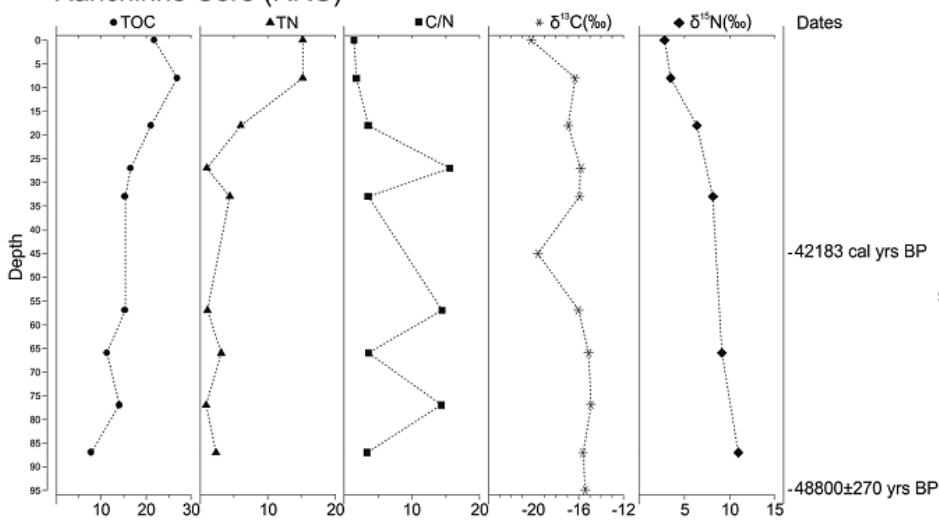

Cerrado Ecological Station (CES)

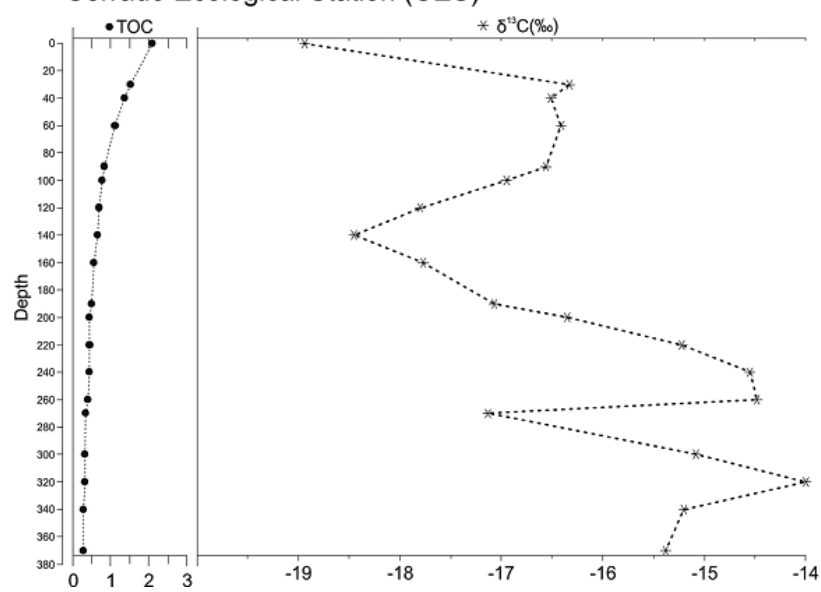

Figure 2. Elementary and isotopic analyses of $\mathrm{C}$ and $\mathrm{N}$ (TOC, Total Organic Carbon; TN, Total Nitrogen; C/N, $\delta^{13} \mathrm{C}$ and $\delta^{15} \mathrm{~N}$ ), and $\delta^{13} \mathrm{C}$ and $\mathrm{C} / \mathrm{N}$ correlation.
- Zone II $(50-40 \mathrm{~cm})$ was dated $\sim 42,183 \mathrm{cal}$ yrs BP at $45 \mathrm{~cm}$ depth. In this zone, the reduction of Elongate and Parallelepipedal bulliform morphotypes and the occurrence of Globular echinate and Globular psilate were observed, associated with Arecaceae, Bromeliaceae, and ligneous dicotyledons.

- In Zone III $(40-20 \mathrm{~cm})$, the reduced occurrence of globular morphotypes was noted, with the presence of more robust forms (Parallelepipedal bulliform, Cuneiform bulliform and Elongate).
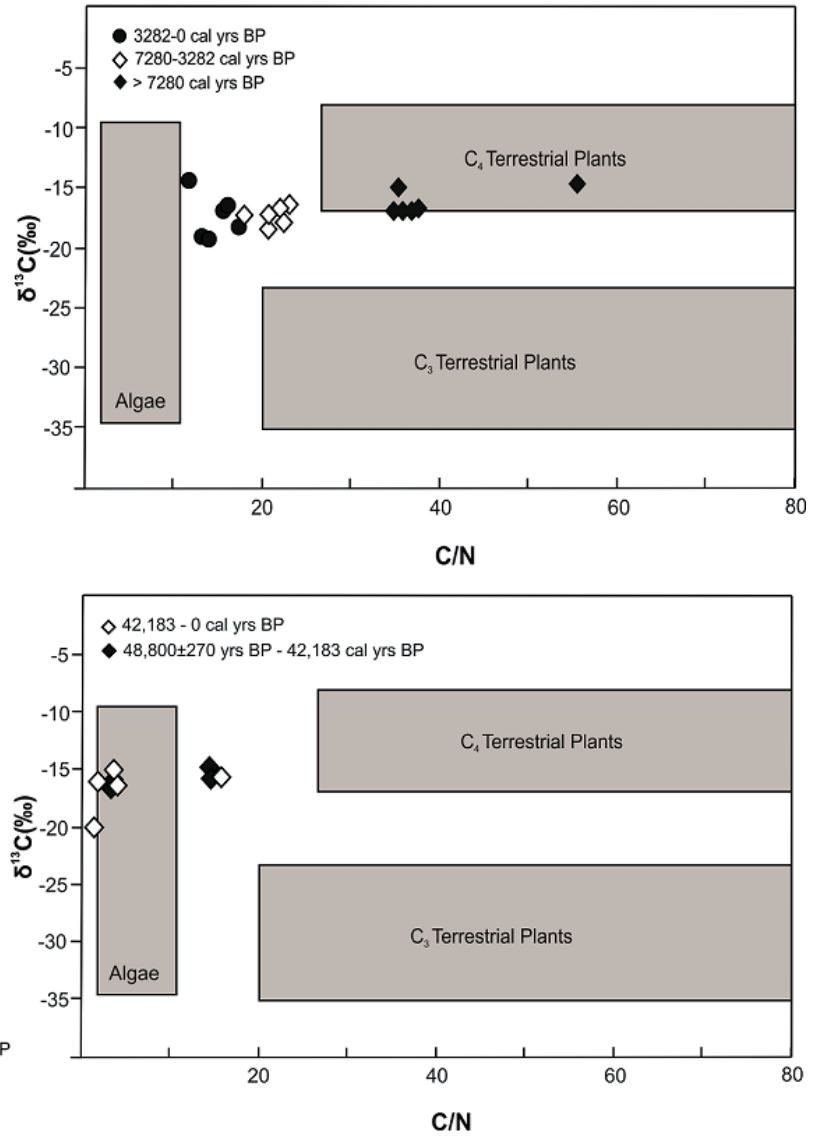

I 5820 cal yrs BP

- In Zone IV $(20-0 \mathrm{~cm})$, the phytolith assemblage becomes more varied, with the presence of Bilobate and other short cells morphotypes (Cross, Rondel, and Trapeziform) associated with the presence of Poaceae without water stress. Globular morphotypes occur again.

Água dos Papagaios Core (APC). Four phytolith zones were also established in APC (Figure 4, Appendix 2):

- Zone I $(110-100 \mathrm{~cm})$. The most representative phytoliths were the short cells (Bilobate, Saddle, and Rondel); 
Table 4. Values of C (\%), N (\%), $\delta 13 \mathrm{C}, \delta 15 \mathrm{~N}$, and C/N (Água dos Papagaios).

\begin{tabular}{|c|c|c|c|c|c|}
\hline Depth $(\mathrm{cm})$ & C (\%) & $\delta^{13} \mathrm{C}$ & $\mathrm{N}(\%)$ & $\delta^{15} \mathrm{~N}$ & $\mathrm{C} / \mathrm{N}$ \\
\hline 0 & - & - & 1.76 & 4.77 & - \\
\hline 5 & 23.62 & -19.04 & 1.76 & 5.32 & 13.42 \\
\hline 10 & 26.36 & -19.2 & 1.85 & 4.72 & 14.23 \\
\hline 15 & 29.64 & -16.48 & 1.86 & 4.25 & 15.90 \\
\hline 20 & 27.68 & -16.62 & 1.71 & 4.4 & 16.23 \\
\hline 25 & 25.93 & -16.5 & 1.59 & 4.48 & 16.32 \\
\hline 30 & 24.19 & -16.21 & 1.47 & 4.68 & 16.46 \\
\hline 35 & 18.33 & -18.03 & 1.03 & 6.75 & 17.76 \\
\hline 40 & 18.04 & -17.90 & 0.85 & 7.99 & 21.34 \\
\hline 45 & 17.25 & -17.93 & 0.80 & 6.56 & 21.53 \\
\hline 50 & 16.00 & -17.44 & 0.70 & 5.95 & 22.96 \\
\hline 55 & 17.45 & -17.22 & 0.96 & 4.7 & 18.22 \\
\hline 60 & 19.67 & -17.06 & 0.93 & 5.09 & 21.10 \\
\hline 65 & 19.08 & -16.23 & 0.85 & 6.97 & 22.34 \\
\hline 70 & 13.55 & -16.23 & 0.59 & 8.42 & 23.01 \\
\hline 75 & 8.06 & -14.85 & 0.22 & 18.9 & 35.96 \\
\hline 80 & 6.78 & -14.52 & 0.12 & 3.19 & 56.47 \\
\hline 85 & 6.86 & -16.47 & 0.18 & 3.2 & 38.13 \\
\hline 90 & 10.22 & -16.64 & 0.28 & 3.15 & 36.48 \\
\hline 95 & 9.59 & -17.01 & 0.27 & 2.49 & 35.53 \\
\hline 100 & 12.49 & -16.76 & 0.33 & 3.26 & 37.83 \\
\hline 110 & 0.48 & -14.24 & 0.04 & 4.13 & 12.03 \\
\hline
\end{tabular}

Table 5. Values of C (\%), N (\%), $\delta 13 \mathrm{C}$, and C/N (Ranchinho).

\begin{tabular}{ccccc}
\hline Depth $(\mathrm{cm})$ & $\mathrm{C}(\%)$ & $\mathrm{N}(\%)$ & $\delta^{13} \mathrm{C}$ & $\mathrm{C} / \mathrm{N}$ \\
\hline $28-25$ & 16.48 & 1.01 & -15.8 & 15.61 \\
$43-40$ & - & - & -19.6 & - \\
$58-55$ & 15.28 & 1.10 & -16 & 14.46 \\
$79-75$ & 14.05 & 0.84 & -14.9 & 14.36 \\
$97-94$ & - & - & -15.4 & - \\
\hline
\end{tabular}

characteristic of Poaceae, with a low incidence of bulliform forms (Parallelepipedal and Cuneiform).

- Zone II (100-60 cm), 7280 cal yrs BP at $75 \mathrm{~cm}$ depth, shows a progressive increase in forms of bulliform (Parallelepipedal and Cuneiform). Zone III $(60-35 \mathrm{~cm})$, $\sim 3282$ cal yrs BP at $45 \mathrm{~cm}$, presents a reduction of morphotypes Parallelepipedal bulliform and Cuneiform bulliform, with a progressive increase of short cells. A reduction in the occurrence of Globular echinate and lobular psilate (characteristics of Arecaceae, Bromeliaceae, and ligneous dicotyledons) was also observed, suggesting the predominance of Poaceae.

- Zone IV (35-0 cm) presents modern vegetation characteristics, composed mainly by small morphotypes (Poaceae), with minor variations in the composition of phytoliths. At $15 \mathrm{~cm}$ depth, there is a slight increase in the occurrence of Parallelepipedal and Cuneiform bulliform forms. 
Table 6. Values of $\mathrm{C}(\%)$ and $\delta 13 \mathrm{C}$ (Cerrado Ecological Station).

\begin{tabular}{|c|c|c|}
\hline Depth $(\mathrm{CM})$ & $\mathrm{C}(\%)$ & $\delta^{13} \mathrm{C}$ \\
\hline $0-10$ & 2.10 & -18.94 \\
\hline $30-40$ & 1.52 & -16.33 \\
\hline $40-50$ & 1.37 & -16.51 \\
\hline $60-70$ & 1.12 & -16.41 \\
\hline $90-100$ & 0.84 & -16.56 \\
\hline $100-110$ & 0.78 & -16.95 \\
\hline $120-130$ & 0.69 & -17.80 \\
\hline $140-150$ & 0.66 & -18.45 \\
\hline $160-170$ & 0.56 & -17.77 \\
\hline $190-200$ & 0.50 & -17.07 \\
\hline $200-210$ & 0.44 & -16.35 \\
\hline $220-230$ & 0.45 & -15.22 \\
\hline $240-250$ & 0.44 & -14.55 \\
\hline $260-270$ & 0.41 & -14.48 \\
\hline $270-280$ & 0.35 & -17.13 \\
\hline $300-310$ & 0.33 & -15.08 \\
\hline $320-330$ & 0.33 & -14.00 \\
\hline $340-350$ & 0.29 & -15.20 \\
\hline $370-380$ & 0.28 & -15.38 \\
\hline
\end{tabular}

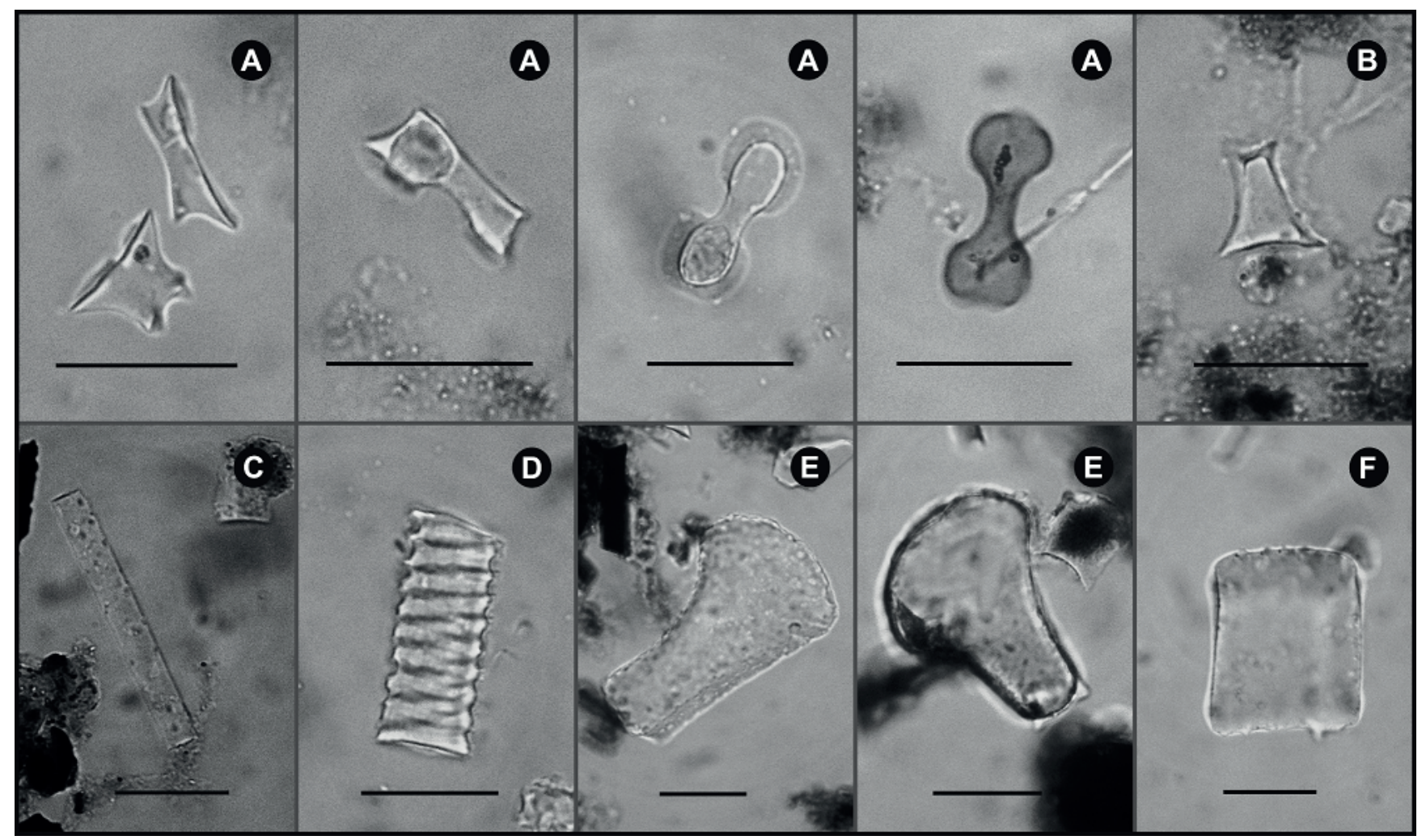

Figure 3. Main phytolith morphotypes classified from the peaty sediment samples: A, Bilobate; B, Rondel; C, Elongate psilate; D, Cylindrical sulcate tracheid; E, Cuneiform bulliform; F, Parallepipedal bulliform. Scale bars $=25 \mu \mathrm{m}$. 

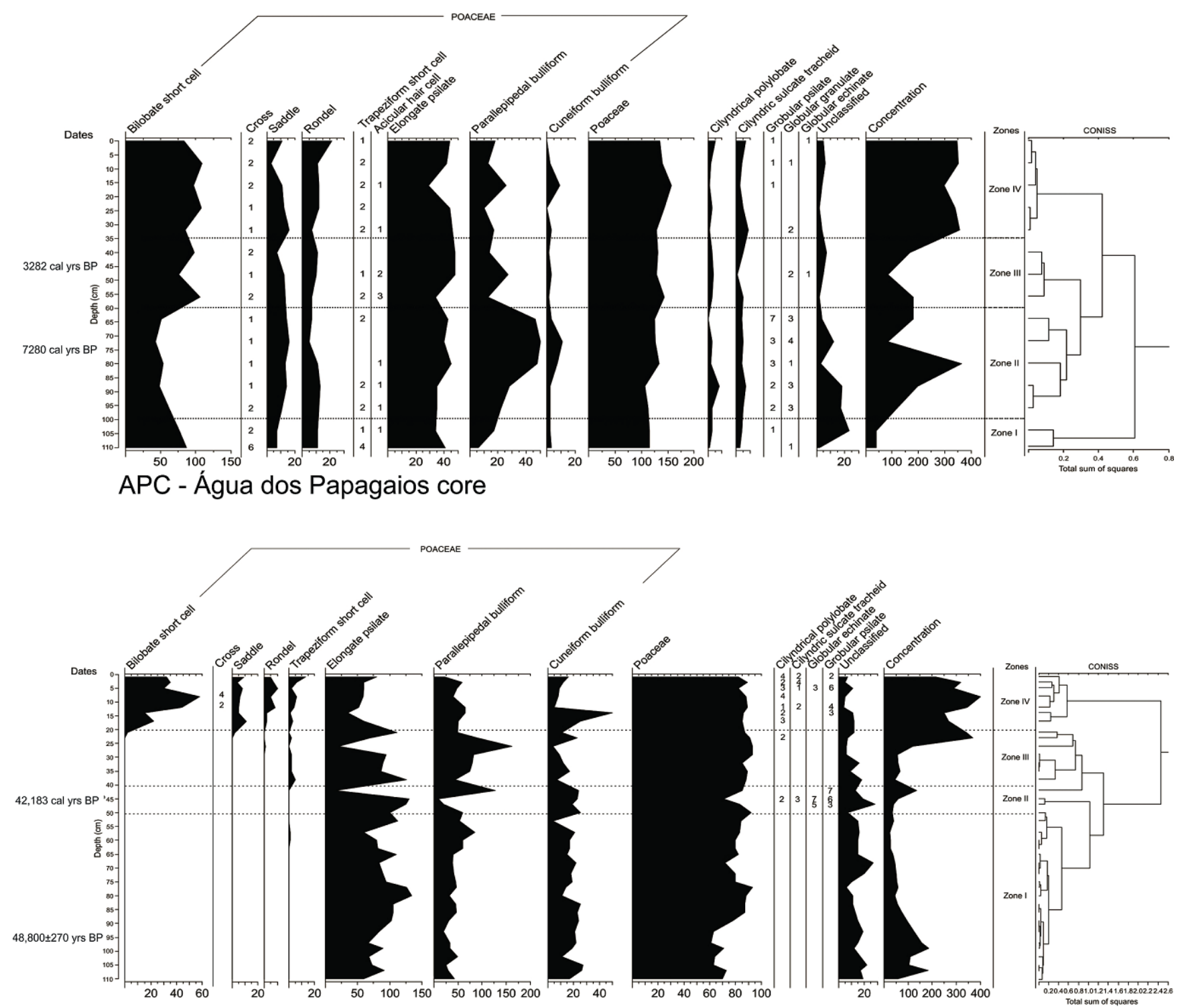

RRC - Ranchinho core

Figure 4. Diagram of phytolith morphotypes and zones identified in the sedimentary profiles.

\section{DISCUSSION}

Unclassified morphotypes, as well as the corrosion of phytolith surfaces decreased, progressively towards the top. This result may be related to the natural process of phytolith dissolution, where only robust forms resist destruction (Alexandre et al., 1997; Barboni et al., 1999; Borba-Roschel et al., 2006; Coe et al., 2013). According to Cabanes \& ShahackGross (2015), partial dissolution of phytoliths may be related to the bulk ratio of the individual morphotype.

Phytolith assemblages, $\delta^{13} \mathrm{C}$ and $\delta^{15} \mathrm{~N}$ values, TN, TOC and $\mathrm{C} / \mathrm{N}$ in Zone I of the RRC, dated 48,800 $\pm 270 \mathrm{yrs} \mathrm{BP}$ reflects abundance in $\mathrm{C}_{4}$ plants. The higher presence of bulliform morphotypes is probably associated with hydric stress (Parry \& Smithson, 1958). Bremond et al. (2005) found that the silicification of the bulliform cells is related to the hydric stress in Poaceae and Cyperaceae. Furthermore, higher silicification of bulliform cells is also associated to leaf aging (older leaves deposit more silica in bulliform cells than young leaves), and to transpiration rate (higher transpiration, higher silicification) (Takeoka et al., 1984; Fernández Honaine \& Osterrieth, 2012). The $\mathrm{C} / \mathrm{N}$ and $\delta^{15} \mathrm{~N}$ data indicate the phytoplankton is an important source for the origin of the sediment organic matter. However, even in dry periods, the Ranchinho River alluvial plain probably helped to maintain wet conditions in the sampling site. Similarly, Behling (2002) also noticed a drier phase $\sim 48,000$ yrs BP, with the expansion of grasses under colder conditions in the Southern and Southeastern Brazil.

In the RRC Zone II there are more occurrences of globular morphotypes. According to the literature, Globular echinate is produced mainly by Arecaceae (Piperno \& Jones, 2003; 
Bremond et al., 2005; Rasbold et al., 2011) and Bromeliaceae (Kealhofer \& Piperno, 1998). Globular psilate was recorded for Euphorbiaceae and Proteaceae by Mercader et al. (2009) and by Raitz (2012) for pteridophytes, Orchidaceae, Meliaceae, Lauraceae and Salicaceae, and in fewer instances for the family Poaceae. All of these vegetation occurrences are associated with a humid climate. More depleted $\delta^{13} \mathrm{C}$ values of $\sim 19 \%$, suggest a more important presence of $\mathrm{C}_{3}$ plants in a mixture with $\mathrm{C}_{4}$ plants (Pessenda et al., 1996, 1998), probably associated with the expansion of the arboreal vegetation over the $\mathrm{C}_{4}$ herbs/ grasses due to a more humid climate than in the previous period. The $\mathrm{C} / \mathrm{N}$ values are lower $(\sim 14.4)$ in the sediment organic matter, which also indicates an increase of precipitation (Meyers, 1994). This interpretation agrees with Behling (2006), who suggested wetter climatic conditions from $\sim 42,840$ to $\sim 41,470$ yrs BP in Cambará do Sul/RS (Southern Plateau).

In the zone IV of the RCC the addition of the Bilobate morphotype is associated with Poaceae and Panicoideae, adapted to higher humidity or available moisture in the soil (Barboni et al., 1999, Bremond et al., 2005). The association of these morphotypes with the decrease of bullifoms and globular accretion reaffirm the interpretation of increased humidity in the uppermost $20 \mathrm{~cm}$ of the core. The $\mathrm{C} / \mathrm{N}<5$ ratio indicates a high influence of organic matter of aquatic origin. The concentration of phytoliths becomes more expressive (>300 phytoliths), and there is a more significant deposition of bulliforms (predominance of Parallelepipedal) in zone II of the APC core. The $\delta^{13} \mathrm{C}$ values suggest the dominance of $\mathrm{C}_{4}$ grasses adapted to drier conditions, and at $\sim 7280 \mathrm{cal} \mathrm{yrs}$ $\mathrm{BP}, 75 \mathrm{~cm}$ depth, an abrupt increase in the $\mathrm{C} / \mathrm{N}$ value $(\sim 56.47)$ is indicative of an input of terrestrial $\mathrm{C}_{4}$ plant organic matter in association with the increase of $\delta^{15} \mathrm{~N}$ and its highest value $(\sim 18.9 \%$ ) since the early Holocene at the APC site. Isotopic data progressively changing to more depleted values of $\delta^{13} \mathrm{C}$
(-18.45\%) up to $7280 \mathrm{yrs}$ cal BP in APC indicates a mixture of $\mathrm{C}_{3}$ and $\mathrm{C}_{4}$ plants and is probably related to a more humid climate. The $\delta^{15} \mathrm{~N}$ values $(\sim 5 \%)$ suggest the presence of phytoplankton in the sediment organic matter (Meyers 1994, 2006; Meyers \& Ishiwatari, 1993).

Pessenda et al. (1996) reported a drier climate with the predominance of $\mathrm{C}_{4}$ plants from the Late Pleistocene $(\sim 10,530$ cal yrs BP) to the Middle Holocene in an oxisol profile in the region of Londrina (Northern Paraná State), $200 \mathrm{~km}$ from the study area. It is probably associated with the Pleistocene expansion of Cerrado. Gouveia et al. (2002) reported the presence of $\mathrm{C}_{4}$ plants in the Upper Pleistocene of Jaguariaíva (Paraná State), progressively changing with a mixture of $\mathrm{C}_{3}$ plants in the Lower Holocene. A similar tendency is observed at CES, as the dominance of $\mathrm{C}_{4}$ plants ( $-14 \%$ to $-15.38 \%$ ) from the lowermost layer up to $300 \mathrm{~cm}$ depth is probably associated with a drier climate.

The presence of a drier period up to $\sim 7000 \mathrm{yrs}$ BP is also attested by other studies conducted near the study area (e.g. Stevaux, 2000; Behling, 2006; Parolin et al., 2008; Guerreiro et al., 2013, and others) (Figure 5). The modern predominant humid climate conditions were established $\sim 4000-3000 \mathrm{cal}$ yrs BP in the northern Paraná (Pessenda et al., 1996, 1998a) and São Paulo states (Pessenda et al., 1996, 1998a; Gouveia et al., 2002; Scheel-Ybert et al., 2003). Behling (1998) noticed the expansion of Araucaria over areas previously dominated by grasses, $\sim 2872$ yrs cal BP in a more humid climate in the region of Campos Gerais, Paraná.

Stevaux (2000) and Parolin et al. (2008) registered a drier period between 3500-1500 yrs BP in the Paraná River floodplain, located $\sim 200 \mathrm{~km}$ from our study site. However, this drier period was not observed in this study. In the same paper, Stevaux (2000) stated that the current conditions of climate and vegetation were established from 1500 yrs BP onward.

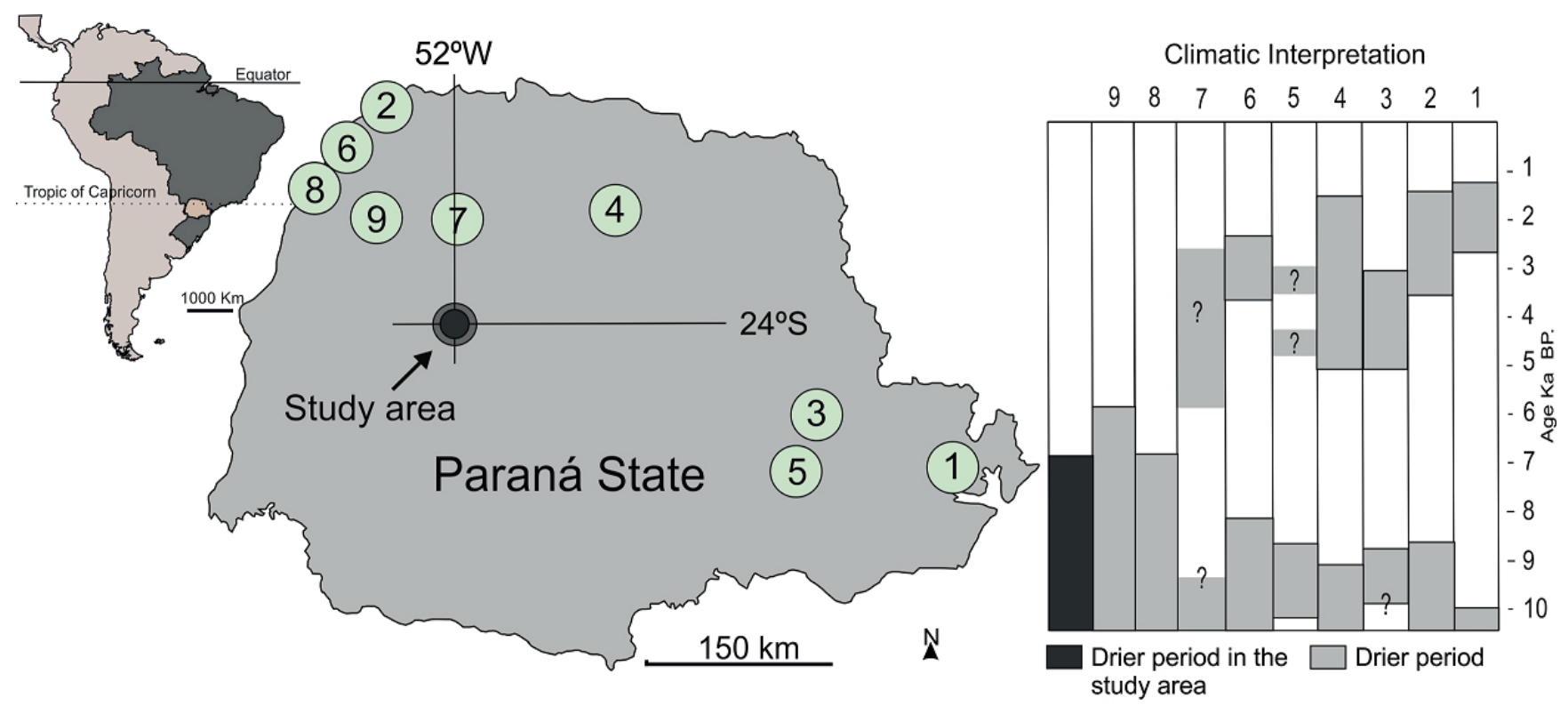

(1) Bigarella \& Andrade-Lima (1982); (2) Jabur (1992), Stevaux (1994); (3) Melo et al. (2003); (4) Pessenda et al. (2004); (5) Moro et al. (2004); (6) Stevaux (2000); (7) Rezende (2010); (8) Guerreiro et al. (2013); (9) Alcantara-Santos et al. (2014)

Figure 5. Climatic interpretation given by this study compared with selected studies in the Paraná State during the Holocene. 


\section{CONCLUSIONS}

The application of phytolith analysis and isotopic and elementary $\mathrm{C}$ and $\mathrm{N}$ data has provided strong evidence for environmental changes since the Late Pleistocene in the Campo Mourão region. The results reflect the presence of grasses in the sampling location since $\sim 48,800$ years BP, including the Last Glacial Maximum, and suggesting the presence of Cerrado since the Late Pleistocene. In general, we can infer that at $\sim 48,800 \mathrm{yrs} B$, the vegetation was composed mainly of Poaceae, with an expansion of ligneous plants in a wetter phase $\sim 42,280$ cal yrs BP. In the Água dos Papagaios core, a drier period was identified during the Middle Holocene ( 7280 cal yrs BP). The present climatic conditions were established at $3282 \mathrm{cal}$ yrs BP with short variations in the phytolith composition, elementary, and isotopic data. In summary, since the Early Holocene, the arboreal vegetation has increasingly expanded over the Cerrado areas in the last $\sim 3282$ cal yrs BP. Our results corroborate Maack (1949)'s hypothesis, which proposes that the Cerrado origin was related to the drier climate conditions during the Late Pleistocene.

\section{ACKNOWLEDGMENTS}

The first author acknowledges CAPES for the Ph.D. Scholarship. The authors acknowledge the CNPq (National Council for Technology and Scientific Research) for financial support (Grant 471.385/2012-3) and the HCF herbarium staff for assistance. The second author thanks the Fundação Araucária for research fellowship. The authors also would like to acknowledge the two anonymous reviewers for the comments about this study.

\section{REFERENCES}

Alcantara-Santos, J.; Gasparetto, N. \& Parolin, M. 2014. Reconstrução paleoambiental do Baixo Curso do rio Ivaí Douradina/Paraná. Geografia, 39:337-350.

Alexandre, A.; Meunier, J.; Colin, F. \& Koud, J. 1997. Plant impact on the biogeochemical cycle of silicon and related weathering processes. Geochimica et Cosmochimica Acta, 61:677-682. doi:10.1016/S0016-7037(97)00001-X

Alexandre, A.; Meunier, J.; Mariotti, A. \& Soubies, F. 1999. Late Holocene Phytolith and Carbon-Isotope Record from a Latosol at Salitre, South-Central Brazil. Quaternary Research, 51:187-194. doi:10.1006/qres.1998.2027

Andrade, A. \& Nery, J. 2003. Análise da precipitação diária, mensal e interanual da bacia hidrográfica do rio Ivaí, Brasil. Investigaciones geográficas, 52:7-30.

Barboni, D.; Bonnefille, R.; Alexandre, A. \& Meunier, J. 1999. Phytoliths as paleoenvironmental indicators, West Side Middle Awash Valley, Ethiopia. Palaeogeography, Palaeoclimatology, Palaeoecology, 152:87-100. doi:10.1016/ S0031-0182(99)00045-0

Behling, H. 1998. Late Quaternary vegetational and climatic changes in Brazil. Review of Palaeobotany and Palynology, 99:143-156. doi:10.1016/S0034-6667(97)00044-4
Behling, H. 2002. South and Southeast Brazilian grasslands during late Quaternary times: a synthesis. Palaeogeography, Palaeoclimatology, Palaeoecology, 177:19-27. doi:10.1016/ S0031-0182(01)00349-2

Behling, H. 2006. Late Quaternary vegetation, fire and climate dynamics of Serra do Araçatuba in the Atlantic Coastal Mountains of Paraná State, Southern Brazil. Vegetation History and Archaeobotany, 16:77-85. doi:10.1007/s00334-006-0078-2

Behling, H. \& Negrelle, R. 2001. Tropical rain forest and climate dynamics of the atlantic lowland, Southern Brazil, during the late Quaternary. Quaternary Research, 56:383-389. doi:10.1006/ qres.2001.2264

Behling, H. \& Safford, H. 2010. Late-Glacial and Holocene vegetation, climate and fire dynamics in the Serra Dos Órgãos, Rio de Janeiro State, Southeastern Brazil. Global Change Biology, 16:1661-1671. doi:10.1111/j.1365-2486.2009.02029.x

Bigarella, J. \& Andrade-Lima, D. 1982. Paleoenvironmental changes in Brazil. In: G.T Prance (ed.) Biological diversification in the tropics, Columbia Press, p. 27-39.

Borba-Roschel, M.; Alexandre, A.; Varajão, A.F.D.C.; Meunier, J.D.; Varajão, C.A.C. \& Colin, F. 2006. Phytoliths as indicators of pedogenesis and paleoenvironmental changes in the Brazilian Cerrado. Journal of Geochemical Exploration, 88:172-176. doi:10.1016/j.gexplo.2005.08.032

Boutton, T.W. 1991. Stable carbon isotope ratios of natural materials. In: D.C Coleman \& B. Fry (eds.) Carbon Isotope Techniques, Academic Press, p. 173-185.

Bremond, L.; Alexandre, A.; Peyron, O. \& Guiot, J. 2005. Grass water stress estimated from phytoliths in West Africa. Journal of Biogeography, 32:311-327. doi:10.1111/j.13652699.2004.01162.x

Cabanes, D. \& Shahack-Gross, R. 2015. Understanding fossil phytolith preservation: the role of partial dissolution in paleoecology and archaeology. PLOS ONE, 10:e 0125532. doi:10.1371/journal.pone.0125532

Calegari, M.R.; Madella, M.; Buso, Jr. A.A.; Osterrieth, M.L.; Lorente, F.L. \& Pessenda L.C.R. 2015. Holocene vegetation and climate inferences from phytoliths and pollen from Lagoa do Macuco, North Coast of Espírito Santo State (Brazil). Quaternary and Environmental Geosciences, 6:41-50. doi:10.5380/abequa. v6i1.36426

Calegari, M.R.; Madella, M.; Vidal-Torrado, P.; Pessenda, L.C.R. $\&$ Marques, F.A. 2013. Combining phytoliths and $\delta^{13} \mathrm{C}$ matter in Holocene palaeoenvironmental studies of tropical soils: an example of an oxisol in Brazil. Quaternary International, 287:47-55. doi:10.1016/j.quaint.2011.11.012

Coe, H.H.G.; Alexandre, A.; Carvalho, C.N.; Santos, G.M.; Silva, A.S.; Sousa, L.O.F. \& Lepsch, I.F. 2013. Changes in Holocene tree cover density in Cabo Frio (Rio de Janeiro, Brazil): evidence from soil phytolith assemblages. Quaternary International, 287:63-72. doi:10.1016/j.quaint.2012.02.044

Coe, H.H.G. \& Osterrieth, M.L. 2014. Synthesis of some phytoliths studies in South America (Brazil and Argentina). New York, Nova Publishers, 270 p.

Cohen, M.C.L.; Pessenda, L.C.R.; Behling, H.; Rossetti, D.F.; França, M.C.; Guimarães, J.T.F.; Friaes, Y. \& Smith, C.B. 2012. Holocene palaeoenvironmental history of the amazonian mangrove belt. Quaternary Science Reviews, 55:50-58. doi:10.1016/j.quascirev.2012.08.019

Eiten, G. 1972. The Cerrado vegetation of Brazil. The Botanical Review, 38:201-341. doi:10.1007/BF02859158 
Faegri, K. \& Iversen, J. 1975. A textbook for pollen analysis. $3^{\text {rd }} \mathrm{ed}$. New York, Haffer, 145 p.

Fernández Honaine, M. \& Osterrieth, M. L. 2012. Silicification of the adaxial epidermis of leaves of a panicoid grass in relation to leaf position and section and environmental conditions. Plant Biology, 14:596-604. doi:10.1111/j.1438-8677.2011.00530.x

Freitas, H.A.; Pessenda, L.C.R.; Aravena, R.; Gouveia, S.E.M.; Ribeiro, A.S. \& Boulet, R. 2001. Late Quaternary vegetation dynamics in the Southern Amazon basin inferred from carbon isotopes in soil organic matter. Quaternary Research, 55:39-46. doi:10.1006/qres.2000.2192

Gouveia, S.E.M.; Pessenda, L.C.R.; Aravena, R.; Boulet, R.; Scheel-Ybert, R.; Bendassoli, J.A; Ribeiro, A.S. \& Freitas, H.A. 2002. Carbon isotopes in charcoal and soils in studies of paleovegetation and climate changes during the late Pleistocene and the Holocene in the Southeast and Centerwest Regions of Brazil. Global and Planetary Change, 33:95-106. doi:10.1016/ S0921-8181(02)00064-4

Guerreiro, R.L.; Stevaux, J.C.; Parolin, M. \& Assine, M.L. 2013. Late Pleistocene and Holocene paleoenvironments in ponds and alluvial sediments of Upper Paraná River, Brazil. Revista Brasileira de Paleontologia, 16:39-46. doi:10.4072/ rbp.2013.1.03

Jabur, I.C. 1992. Análise paleoambiental do Quaternário Superior na Bacia do Alto Paraná. Instituto de Geociências e Ciências Exatas, Universidade Estadual Paulista, Tese de Doutorado, $184 \mathrm{f}$.

Kealhofer, L. \& Piperno, D.R. 1998. Opal phytoliths in southeast Asian Flora. Smithsonian Contributions to Botany, 88:1-39.

Klink, C.A. \& Machado, R.B. 2005. Conservation of the Brazilian Cerrado. Conservation Biology, 19:707-713. doi:10.1111/j.15231739.2005.00702.x

Ledru, M.P.; Braga, P.I.S.; Soubiès, F.; Fournier, M.; Martin, L.; Suguio, K. \& Turcq, B. 1996. The last 50,000 years in the Neotropics (Southern Brazil): evolution of vegetation and climate. Palaeogeography, Palaeoclimatology, Palaeoecology, 123:239-257. doi:10.1016/0031-0182(96)00105-8

Luz, L.D. \& Parolin, M. 2013. Caracterização dos sedimentos turfosos em Campo Mourão, Paraná, Brasil. Revista Brasileira de Geografia Física, 7:319-326.

Maack, R. 1949. Notas complementares à apresentação preliminar do mapa fitogeográfico do Estado do Paraná (Brasil). Arquivos do Museu Paranaense, 7:351-362.

Madella, M.; Alexandre, A. \& Ball, T. 2005. International code for phytolith nomenclature 1.0. Annals of Botany, 96:253-260. doi:10.1093/aob/mci172

Martin, L.; Flexor, J.M. \& Suguio, K. 1995. Vibrotestemunhador leve: construção, utilização e potencialidades. Revista do Instituto de Geociências, 16:59-66. doi:10.5935/0100-929X.19950004

Melo, M.S.; Giannini, P.C.F.; Pessenda, L.C.R. \& Brandt, N.M. 2003. Holocene paleoclimatic reconstruction based on the Lagoa Dourada deposits, Southern Brazil. Geologica Acta, 3:289-302. doi:10.1344/105.000001616

Mercader, J.; Bennett, T.; Esselmont, C.; Simpson, S. \& Walde, D. 2009. Phytoliths in woody plants from the Miombo Woodlands of Mozambique. Annals of Botany, 104:91-113. doi:10.1093/ aob/mcp097

Meunier, J.D. \& Colin, F. 2001. Phytoliths: applications in Earth Sciences and Human History. London, Balkema Publishers, $378 \mathrm{p}$.

Meyers, P.A. 1994. Preservation of elemental and isotopic source identification of sedimentary organic matter. Cheminal Geology, 114:289-302. doi:10.1016/0009-2541(94)90059-0
Meyers, P.A. 2006. An overview of sediment organic matter records of human eutrophication in the Laurentian Great Lakes Region. In: B. Kronvang; J. Fagareli \& N. Ogrinc (eds.) The interactions between sediments and water, Springer, p. 89-99. doi:10.1007/978-1-4020-5478-5_10

Meyers, P.A. \& Ishiwatari, R. 1993. Lacustrine organic geochemistry - an overview of indicators of organic-matter sources and diagenesis in lake-sediments. Organic Geochemistry, 20:867900. doi:10.1016/0146-6380(93)90100-P

Mineropar, Minérios do Paraná S/A. 2001. Avaliação do potencial mineral e consultoria técnica no município de Barbosa Ferraz. Available at http://www.mineropar.pr.gov.br/arquivos/File/ publicacoes/relatorios_concluidos/18_relatorios_concluidos. pdf; accessed in 8/5/2015.

Moro, R.S.; Bicudo, C.E.M.; Melo, S.M. \& Schmitt, J. 2004. Paleoclimate of the Late Pleistocene and Holocene at Lagoa Dourada, Paraná State, Southern Brazil. Quaternary International, 114:87-99. doi:10.1016/S1040-6182(03)00044-2

Parolin, M.; Volkmer-Ribeiro, C. \& Stevaux, J.C. 2008. Use of spongofacies as a proxy for river-lake paleohydrology in quaternary deposits of Central-Western Brazil. Revista Brasileira de Paleontologia, 11:187-98. doi:10.4072/rbp.2008.3.05

Parry, W.D \& Smithson, F. 1958. Silicification of bulliform cells in grasses. Nature, 181:1549-1550. doi:10.1038/1811549b0

Pessenda, L.C.R.; Gomes, B.M.; Aravena, R.; Ribeiro, A.S.; Boulet, R. \& Gouveia, S.E.M. 1998b. The carbon isotope record in soils along a forest-cerrado ecosystem transect: implications for vegetation changes in the Rondonia State, Southwestern Brazilian Amazon Region. The Holocene, 8:599-603. doi:10.1191/095968398673187182

Pessenda, L.C.R.; Ribeiro, A.S.; Gouveia, S.E.M.; Aravena, R.; Boulet, R. \& Bendassolli, J.A. 2004. Vegetation dynamics during the late Pleistocene in the Barreirinhas Region, Maranhão State, Northeastern Brazil, based on carbon isotopes in soil organic matter. Quaternary Research, 62:183-193. doi:10.1016/j. yqres.2004.06.003

Pessenda, L.C.R.; Valencia, E.P.E.; Aravena, R.; Telles, E.C.C. \& Boulet, R. 1998a. Paleoclimatic studies in Brazil using carbon isotopes in soils. In: J.C. Wasserman; E.V. Silva-Filho \& R. Villas-Boas (eds.) Environmental Geochemistry in the Tropics, Springer, p. 7-16. doi:10.1007/BFb0010902

Pessenda, L.C.R.; Valencia, E.P.E.; Camargo, P.B.; Telles, E.C.C.; Martinelli, L.A.; Cerri, C.C.; Aravena, R. \& Rozanski, K. 1996. Natural radiocarbon measurements in brazilian soils developed on basic rocks. Radiocarbon, 38:203-208.

Pinheiro, M.H.O. \& Monteiro, R. 2010. Contribution to the discussions on the origin of the Cerrado biome: Brazilian savanna. Brazilian Journal of Biology, 70:95-102. doi:10.1590/ S1519-69842010000100013

Piperno, D.R. 1989. The occurrence of phytoliths in the reproductive structures of selected tropical angiosperms and their significance in tropical paleoecology, paleoethnobotany and systematics. Review of Palaeobotany and Palynology, 61:147-173. doi:10.1016/0034-6667(89)90067-5

Piperno, D.R. 2006. Phytoliths: a comprehensive guide for archaeologists and paleoecologists. New York, Altamira Press, $238 \mathrm{p}$.

Piperno, D.R. \& Becker, P. 1996. Vegetational history of a site in the Central Amazon Basin derived from phytolith and charcoal records from natural soils. Quaternary Research, 45:202-209. doi:10.1006/qres.1996.0020

Piperno, D.R \& Jones, J.G. 2003. Paleoecological and archaeological implications of a late Pleistocene/Early Holocene record 
of vegetation and climate from the Pacific Coastal Plain of Panama. Quaternary Research, 59:79-87. doi:10.1016/S00335894(02)00021-2

Raitz, E. 2012. Coleção de referência de silicofitólitos da flora do Sudoeste do Paraná: subsidios para estudos paleoambientais. Programa de Pós-graduação em Geografia, Universidade do Oeste do Paraná, Dissertação de Mestrado, 204 f.

Rapp, G. \& Mulholland, S.C. 1992. Phytolith systematics: emerging issues. New York, Plenum Press, 350 p.

Rasbold, G.G.; Monteiro, M.R.; Parolin, M.; Caxambu, M.G. \& Pessenda, L.C.R. 2011. Caracterização dos tipos morfológicos de fitólitos presentes em Butia paraguayensis (Barb. Rodr.) L. H. Bailey (Arecaceae). Iheringia, série Botânica, 66:265-70.

Reimer, P.J. et al. 2013. IntCal13 and MARINE13 radiocarbon age calibration curves 0-50000 years cal BP. Radiocarbon, 55:1869-1887.doi:10.2458/azu_js_rc.55.16947

Rezende, A.B. 2010. Espículas de esponjas em sedimentos de lagoa como indicador paleoambiental no NW do Estado do Paraná. Programa de Pós-graduação em Análise Geoambiental, Universidade de Guarulhos, Dissertação de Mestrado, 65 f.

Scheel-Ybert, R.; Gouveia, S.E.M.; Pessenda, L.C.R.; Aravena, R.; Coutinho, L.M. \& Boulet, R. 2003. Holocene palaeoenvironmental evolution in the São Paulo State (Brazil), based on anthracology and soil $\delta^{13} \mathrm{C}$ analysis. The Holocene, 13:73-81. doi:10.1191/0959683603hl596rp

Stevaux, J.C. 2000. Climatic events during the Late Pleistocene and Holocene in the Upper Parana River: correlation with NE Argentina and South-Central Brazil. Quaternary International, 72:73-85. doi:10.1016/S1040-6182(00)00023-9
Stevaux, J.C. 1994. Upper Paraná River (Brazil): geomorphology and paleoclimatology. Quaternary International, 21:143-161. doi:10.1016/1040-6182(94)90028-0

Stuiver, M.; Reimer, P.J. \& Reimer, R.W. 2017. CALIB 7.1. Available at http://calib.org; accessed on 01/04/2017.

Takeoka, Y.; Wada, T.; Naito, K. \& Kaufman, P.B. 1984. Studies on silicification of epidermal tissues of grasses as investigated by soft x-ray image analysis: II. Differences in frequency of silica bodies in bulliform cells at different positions in the leaves of rice plants. Japanese Journal of Crop Science, 53:197-203. doi:10.1626/jcs.53.197

Twiss, P.C.; Suess, E. \& Smith, R.M. 1969. Morphological classification of grass phytoliths. Soil Science Society of America Journal, 33:109-115. doi:10.2136/sssaj1969.03615995003300010030x

Zani, H.; Rossetti, D.F.; Cohen, M.L.C.; Pessenda, L.C.R. \& Cremon, E.H. 2012. Influence of landscape evolution on the distribution of floristic patterns in Northern Amazonia revealed by $\delta^{13} \mathrm{C}$ Data. Journal of Quaternary Science, 27:854-864. doi:10.1002/ jqs. 2602

Received in 06 August, 2018; accepted in 08 March, 2019. 
Appendix 1. Phytoliths counting table of the Ranchinho core.

\begin{tabular}{|c|c|c|c|c|c|c|c|c|c|c|c|c|c|c|}
\hline 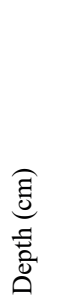 & 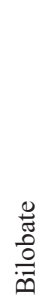 & 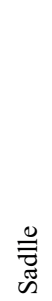 & $\begin{array}{l}\bar{\Phi} \\
\overline{0} \\
\simeq\end{array}$ & 完 & 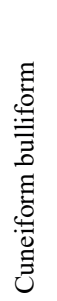 & 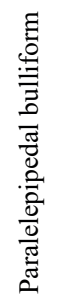 & 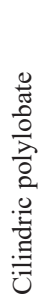 & 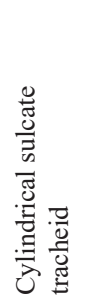 & 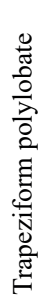 & 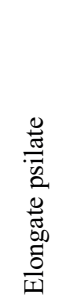 & 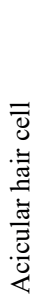 & 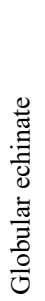 & 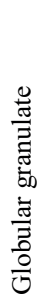 & 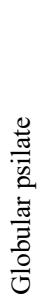 \\
\hline 0 & 32 & 9 & 5 & 0 & 16 & 23 & 4 & 2 & 12 & 80 & 1 & 0 & 0 & 2 \\
\hline 4 & 35 & 4 & 7 & 0 & 12 & 59 & 2 & 4 & 5 & 59 & 0 & 0 & 0 & 0 \\
\hline 7 & 30 & 8 & 10 & 0 & 9 & 48 & 3 & 1 & 2 & 60 & 0 & 0 & 2 & 4 \\
\hline 10 & 58 & 6 & 5 & 4 & 8 & 40 & 4 & 0 & 0 & 59 & 0 & 0 & 0 & 0 \\
\hline 13 & 44 & 5 & 8 & 2 & 5 & 65 & 1 & 2 & 4 & 52 & 0 & 2 & 0 & 2 \\
\hline 16 & 15 & 5 & 2 & 0 & 50 & 65 & 2 & 0 & 0 & 35 & 0 & 0 & 3 & 0 \\
\hline 19 & 22 & 11 & 2 & 0 & 25 & 50 & 3 & 0 & 1 & 60 & 0 & 0 & 0 & 0 \\
\hline 22 & 2 & 2 & 0 & 0 & 11 & 49 & 0 & 0 & 0 & 110 & 0 & 0 & 0 & 0 \\
\hline 25 & 0 & 0 & 0 & 0 & 23 & 90 & 2 & 0 & 0 & 70 & 0 & 0 & 0 & 0 \\
\hline 28 & 0 & 0 & 0 & 0 & 4 & 162 & 0 & 1 & 0 & 21 & 0 & 0 & 0 & 0 \\
\hline 31 & 0 & 0 & 0 & 0 & 9 & 82 & 0 & 0 & 0 & 95 & 0 & 0 & 0 & 0 \\
\hline 34 & 0 & 0 & 0 & 0 & 12 & 80 & 0 & 0 & 0 & 90 & 0 & 0 & 0 & 0 \\
\hline 37 & 0 & 0 & 0 & 0 & 17 & 75 & 0 & 1 & 2 & 85 & 0 & 0 & 0 & 0 \\
\hline 40 & 0 & 0 & 0 & 0 & 7 & 44 & 0 & 0 & 5 & 126 & 2 & 0 & 0 & 0 \\
\hline 43 & 2 & 0 & 1 & 0 & 4 & 147 & 0 & 0 & 0 & 16 & 0 & 0 & 0 & 1 \\
\hline 46 & 0 & 0 & 0 & 0 & 23 & 10 & 2 & 3 & 0 & 130 & 0 & 7 & 0 & 6 \\
\hline 49 & 0 & 0 & 0 & 0 & 19 & 20 & 0 & 0 & 0 & 125 & 0 & 5 & 0 & 3 \\
\hline 52 & 0 & 0 & 0 & 0 & 25 & 60 & 0 & 0 & 0 & 100 & 0 & 0 & 0 & 0 \\
\hline 55 & 0 & 0 & 0 & 0 & 4 & 53 & 0 & 0 & 0 & 110 & 0 & 0 & 0 & 0 \\
\hline 58 & 0 & 0 & 0 & 0 & 21 & 85 & 0 & 0 & 0 & 60 & 0 & 0 & 1 & 0 \\
\hline 61 & 0 & 0 & 0 & 0 & 0 & 0 & 0 & 0 & 0 & 0 & 0 & 0 & 0 & 0 \\
\hline 64 & 0 & 0 & 0 & 0 & 0 & 0 & 0 & 0 & 0 & 0 & 0 & 0 & 0 & 0 \\
\hline 67 & 0 & 0 & 0 & 0 & 15 & 40 & 2 & 0 & 1 & 110 & 0 & 0 & 2 & 0 \\
\hline 70 & 0 & 0 & 0 & 0 & 22 & 39 & 0 & 0 & 0 & 84 & 0 & 0 & 0 & 0 \\
\hline 73 & 0 & 0 & 0 & 0 & 0 & 0 & 0 & 0 & 0 & 0 & 0 & 0 & 0 & 0 \\
\hline 76 & 0 & 0 & 0 & 0 & 0 & 0 & 0 & 0 & 0 & 0 & 0 & 0 & 0 & 0 \\
\hline 79 & 0 & 0 & 0 & 0 & 14 & 47 & 0 & 0 & 0 & 126 & 0 & 0 & 0 & 0 \\
\hline 82 & 0 & 0 & 0 & 0 & 11 & 32 & 0 & 0 & 0 & 134 & 0 & 0 & 0 & 0 \\
\hline 85 & 0 & 0 & 0 & 0 & 25 & 45 & 0 & 0 & 2 & 105 & 0 & 0 & 0 & 0 \\
\hline 88 & 0 & 0 & 0 & 0 & 23 & 46 & 0 & 0 & 0 & 105 & 0 & 0 & 0 & 0 \\
\hline 91 & 0 & 0 & 0 & 0 & 24 & 31 & 0 & 0 & 0 & 102 & 0 & 0 & 0 & 0 \\
\hline 94 & 0 & 0 & 1 & 0 & 21 & 20 & 0 & 1 & 0 & 81 & 0 & 0 & 0 & 0 \\
\hline 97 & 0 & 0 & 0 & 0 & 22 & 33 & 0 & 0 & 0 & 67 & 0 & 0 & 0 & 0 \\
\hline 100 & 0 & 0 & 0 & 0 & 19 & 33 & 0 & 0 & 0 & 90 & 0 & 0 & 0 & 0 \\
\hline 103 & 0 & 0 & 0 & 0 & 11 & 49 & 0 & 0 & 2 & 68 & 0 & 0 & 0 & 0 \\
\hline 106 & 0 & 0 & 0 & 0 & 27 & 26 & 0 & 0 & 0 & 73 & 0 & 0 & 0 & 0 \\
\hline 109 & 0 & 0 & 0 & 0 & 26 & 29 & 0 & 0 & 0 & 92 & 0 & 0 & 0 & 0 \\
\hline 112 & 0 & 0 & 0 & 0 & 17 & 43 & 0 & 0 & 1 & 60 & & 0 & 0 & 0 \\
\hline
\end{tabular}


Appendix 2. Phytoliths counting table of the Água dos Papagaios core.

\begin{tabular}{|c|c|c|c|c|c|c|c|c|c|c|c|c|c|c|}
\hline 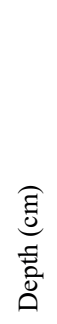 & 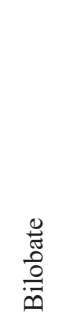 & 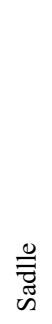 & 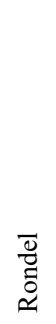 & $\begin{array}{l}n \\
0 \\
0 \\
U\end{array}$ & 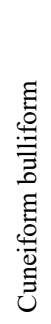 & 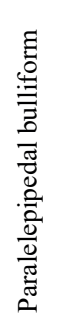 & 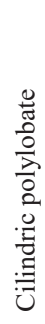 & 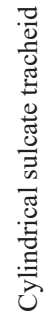 & 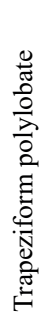 & 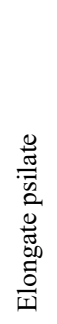 & 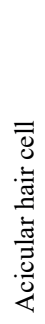 & 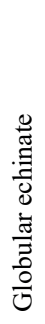 & 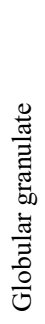 & 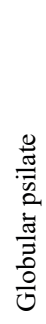 \\
\hline 2 & 83 & 11 & 21 & 2 & 0 & 18 & 5 & 7 & 1 & 44 & 0 & 1 & 0 & 1 \\
\hline 6 & 123 & 1 & 9 & 1 & 0 & 10 & 0 & 4 & 1 & 42 & 0 & 0 & 1 & 2 \\
\hline 10 & 94 & 6 & 13 & 2 & 4 & 15 & 3 & 3 & 3 & 42 & 0 & 0 & 0 & 0 \\
\hline 14 & 77 & 12 & 17 & 1 & 17 & 27 & 1 & 4 & 2 & 27 & 1 & 0 & 0 & 1 \\
\hline 18 & 117 & 9 & 7 & 2 & 0 & 24 & 1 & 2 & 2 & 31 & 0 & 0 & 1 & 0 \\
\hline 22 & 115 & 11 & 5 & 0 & 0 & 9 & 2 & 5 & 1 & 49 & 0 & 0 & 0 & 0 \\
\hline 26 & 100 & 13 & 18 & 1 & 0 & 11 & 4 & 5 & 3 & 39 & 0 & 0 & 0 & 0 \\
\hline 30 & 93 & 5 & 4 & 0 & 1 & 18 & 2 & 14 & 3 & 53 & 0 & 0 & 1 & 0 \\
\hline 34 & 76 & 26 & 10 & 1 & 5 & 16 & 0 & 4 & 1 & 38 & 2 & 0 & 1 & 2 \\
\hline 38 & 111 & 8 & 6 & 1 & 0 & 10 & 4 & 8 & 0 & 37 & 0 & 0 & 0 & 0 \\
\hline 42 & 84 & 6 & 16 & 2 & 1 & 17 & 1 & 1 & 0 & 58 & 0 & 0 & 0 & 0 \\
\hline 46 & 63 & 5 & 10 & 1 & 5 & 52 & 3 & 1 & 1 & 42 & 2 & 1 & 2 & 1 \\
\hline 50 & 88 & 19 & 9 & 1 & 0 & 2 & 4 & 1 & 1 & 54 & 1 & 0 & 0 & 0 \\
\hline 54 & 111 & 17 & 8 & 3 & 0 & 4 & 4 & 6 & 2 & 31 & 1 & 0 & 0 & 0 \\
\hline 58 & 100 & 9 & 5 & 0 & 1 & 22 & 2 & 4 & 2 & 37 & 5 & 0 & 0 & 0 \\
\hline 62 & 55 & 10 & 7 & 0 & 3 & 60 & 0 & 2 & 1 & 40 & 0 & 0 & 0 & 4 \\
\hline 66 & 47 & 18 & 6 & 2 & 2 & 33 & 0 & 6 & 2 & 46 & 0 & 0 & 2 & 7 \\
\hline 70 & 50 & 9 & 5 & 0 & 11 & 46 & 3 & 4 & 0 & 48 & 0 & 0 & 1 & 1 \\
\hline 74 & 35 & 23 & 5 & 1 & 11 & 53 & 2 & 5 & 0 & 32 & 0 & 0 & 1 & 4 \\
\hline 78 & 49 & 11 & 11 & 1 & 14 & 52 & 3 & 4 & 0 & 43 & 1 & 0 & 3 & 2 \\
\hline 82 & 58 & 15 & 11 & 1 & 0 & 44 & 1 & 4 & 0 & 47 & 1 & 0 & 1 & 2 \\
\hline 86 & 48 & 21 & 14 & 2 & 1 & 10 & 9 & 3 & 3 & 42 & 1 & 0 & 0 & 0 \\
\hline 90 & 47 & 7 & 12 & 0 & 2 & 45 & 6 & 10 & 1 & 27 & 1 & 0 & 3 & 1 \\
\hline 94 & 44 & 9 & 14 & 0 & 2 & 35 & 7 & 6 & 2 & 33 & 0 & 0 & 3 & 0 \\
\hline 98 & 67 & 9 & 10 & 0 & 2 & 26 & 5 & 5 & 1 & 40 & 0 & 0 & 0 & 1 \\
\hline 102 & 61 & 13 & 8 & 0 & 0 & 28 & 1 & 4 & 1 & 38 & 1 & 0 & 1 & 0 \\
\hline 106 & 93 & 1 & 13 & 4 & 3 & 6 & 4 & 4 & 1 & 30 & 1 & 0 & 0 & 0 \\
\hline 110 & 87 & 7 & 11 & 6 & 3 & 6 & 1 & 3 & 4 & 41 & 0 & 0 & 0 & 2 \\
\hline
\end{tabular}

